\title{
SURGICAL TREATMENT OF LYMPHEDEMA OF THE PENIS AND SCROTUM
}

\author{
Miguel Modolin, Anuar Ibrahim Mitre, José Carlos Faes da Silva, Wilson Cintra, \\ Ana Paula Quagliano, Sami Arap, Marcus Castro Ferreira
}

\begin{abstract}
Modolin M, Mitre AI, da Silva JCF, Cintra W, Quagliano AP, Arap S, Ferreira MC. Surgical treatment of lymphedema of the penis and scrotum. Clinics. 2006;61(4):289-94.
\end{abstract}

PURPOSE: Lymphedema of the penis and scrotum, regardless of its etiology, is determined by reduced lymphatic flow with subsequent enlargement of the penis and scrotum. The clinical course of this condition is characterized by extreme discomfort for patients, with limitation of local hygiene, ambulation, sexual intercourse, and voiding in the standing position. The purpose of the present study is to present the experience and results of the treatment of lymphedema of the penis and scrotum by removing affected tissues and correcting the penoscrotal region.

MATERIALS AND METHODS: Seventeen patients with lymphedema of the penis and scrotum were treated with a modified Charles procedure, which consists of the excision of the affected skin followed by scrotoplasty and midline suture simulating the scrotal raphe. The penis is covered with a split-thickness skin graft by means of a zigzag suture on its ventral surface.

RESULTS: Regression of symptoms and improvement of previous clinical conditions were verified in the follow-up which ranged from 6 months to 6 years. One patient who had undergone lymphadenectomy with radiation therapy due to penile cancer had recurrent scrotum lymphedema.

CONCLUSIONS: The modified Charles procedure for the treatment of penoscrotal lymphedema is easily reproducible and allows better local hygiene, easier ambulation, voiding in the standing position, resuming sexual intercourse, and finally, better cosmetic results in the affected area with remarkable improvement in quality of life.

KEYWORDS: Elephantiasis. Lymphedema. Penoscrotal. Lymphangiectomy. Surgical treatment.

\section{INTRODUCTION}

The obstruction of lymphatic flow with ductal ectasia leads to hypertrophy and hyperplasia of connective tissue, with interstitial edema infiltrated by cells characterizing a chronic inflammatory process (Figure 1$).^{1-3}$ The thickening of the cutaneous tissue with enlargement of the area affected because of inadequate lymphatic drainage is the main clinical characteristic of lymphedema. ${ }^{4-6}$

The involvement of the external genitalia causing a marked enlargement of its volume (Figure 2) is an uncom-

Plastic Surgery/Urology Faculty of Medicine, University of São Paulo Email: miguelmodolin@uol.com.br

Received for publication on January 27, 2006

Accepted for publication on May, 03, 2006

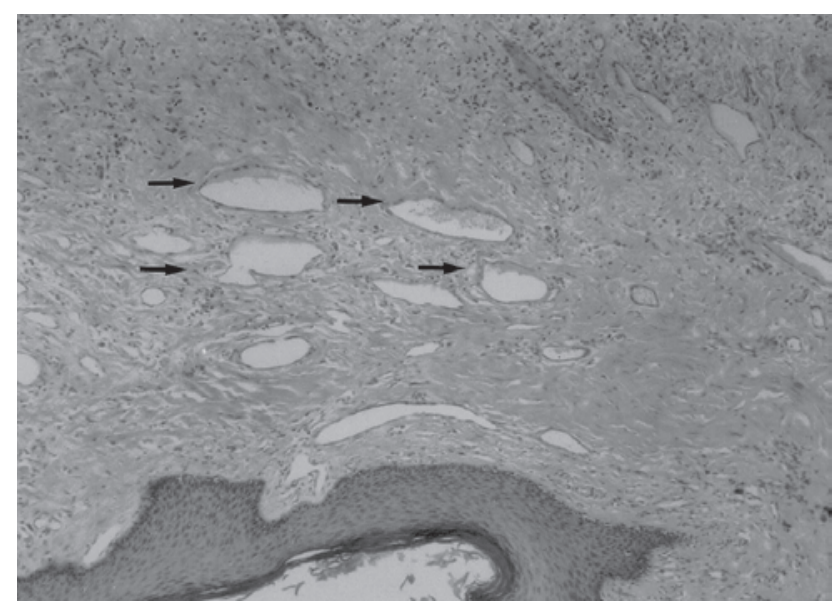

Figure 1 - Microscopic examination of scrotal lesion (1400X magnification). Arrows indicate lymphatic ducts with ectasia and interstitial edema with chronic inflammatory process. 


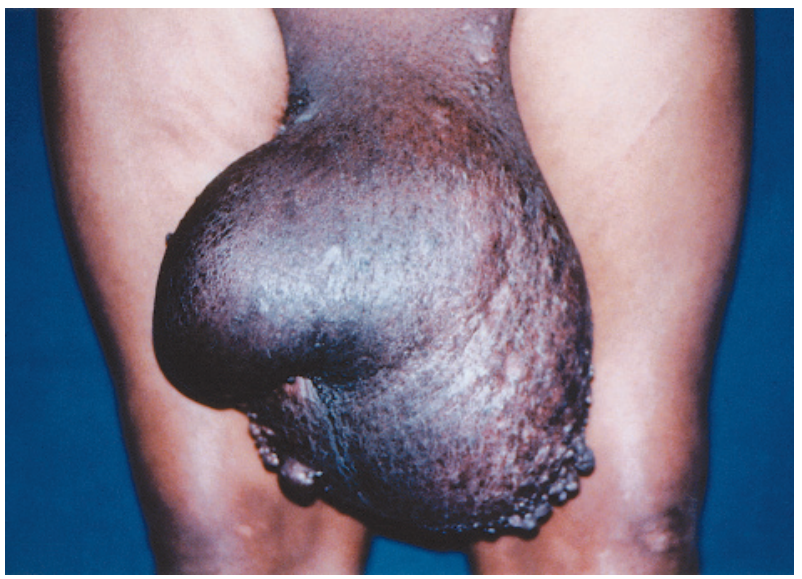

Figure 2 - (Patient 1 of Table 1) - Penoscrotal lymphedema with keratotic lesions in the scrotal region

fortable clinical situation, with impairment of movement, hygiene procedures, voiding in the standing position, and sexual intercourse., ${ }^{4,5,7}$ The lymphedema of the penis and scrotum is classified as primary when it is caused by lymphatic malformation, and as secondary when it results from lymphatic obstruction following parasitic and infectious diseases, or from other clinical conditions such as heart, liver and kidney diseases-or also from surgical or radiation therapy. ${ }^{1,2,8}$

Since the response to medical therapy is poor, excision of the affected tissue is still the best option to treat this condition..$^{7-16}$

The objective of this study is to present our experience in treating penoscrotal lymphedema, as well as the results obtained by using the Charles procedure ${ }^{11}$ and adding a tactical modification in cutaneous reconstruction of the penile shaft.

\section{MATERIALS AND METHODS}

Seventeen patients aged 15 to 72 years mean age: 50.5 years presenting penoscrotal lymphedema with a mean duration of 6.2 years (Table 1) were analyzed and treated.

Patients were assessed by clinical history considering the etiology of the disease, local hygiene conditions, ambulation, associated infections, difficulty of voiding in the standing position, and also as regards sexual intercourse and cosmetic appearance, according to the patient's opinion. Laboratory tests for etiological investigation and preoperative preparation were performed.

Postoperative outcomes were assessed both by patients and the surgical team for a minimum 6-month and a maximum 6-year follow-up period.

\section{Surgical Technique}

Prior to surgery, cleansing of the abdominal region down to the knees with an antiseptic solution and hair removal in the pubic, perineal and inguinal region were performed. Intravenous penicillin $\mathrm{G}$, chloramphenicol, and gentamicin were given prophylactically. The procedure began with incision of the affected skin on the scrotum at the transition to healthy skin in the inguinal, perineal, and crural regions. The testes and spermatic cords were isolated and the tunicae vaginalis were inverted (Figure 3 ). The remaining adjacent skin was used to cover the spermatic cords and testes, and a midline suture simulating the scrotal raphe was performed. The reconstructed scrotum was drained with a continuous drainage tube, which was left in place until the output became lower than $20 \mathrm{~mL}$. The penile skin was excised immediately above Buck's fascia, up to the balanopreputial

Table 1 - Clinical characteristics of the patients treated.

\begin{tabular}{|c|c|c|c|c|}
\hline PATIENT & AGE (years) & $\begin{array}{l}\text { DURATION OF } \\
\text { DISEASE (years) }\end{array}$ & ETIOLOGY & $\begin{array}{l}\text { DURATION OF } \\
\text { FOLLOW-UP }\end{array}$ \\
\hline 1 & 51 & 8 & Lymphogranuloma venereum & 6 years \\
\hline 2 & 15 & 1 & Blastomycosis & 6 years \\
\hline 3 & 48 & 1 & Penile cancer & 5 years \\
\hline 4 & 17 & 4 & Previous drainage of inguinal and perineal abscesses & 1.5 years \\
\hline 5 & 72 & 45 & Filariasis & 4 years \\
\hline 6 & 43 & 0.75 & Tuberculosis & 4 years \\
\hline 7 & 43 & 4 & Filariasis & 4 years \\
\hline 8 & 38 & 3 & Lymphogranuloma venereum & 3 years \\
\hline 9 & 50 & 6 & Obesity & 3 years \\
\hline 10 & 42 & 2 & Filariasis & 2 years \\
\hline 11 & 55 & 7 & Filariasis & 1 year \\
\hline 12 & 38 & 3 & Filariasis & 2 years \\
\hline 13 & 52 & 1 & Previous drainage of inguinal and perineal abscesses & 2 years \\
\hline 14 & 28 & 3 & Syphilis & 1 year \\
\hline 15 & 24 & 7 & Congenital & 1 year \\
\hline 16 & 48 & 4 & Filariasis & 6 years \\
\hline 17 & 22 & 3 & Filariasis & 6 months \\
\hline
\end{tabular}


sulcus. The skinless penile shaft was covered with a splitthickness skin graft harvested from the anterior surface of the thigh. A zigzag suture was performed in the graft on the ventral surface of the penis (Figure 4).

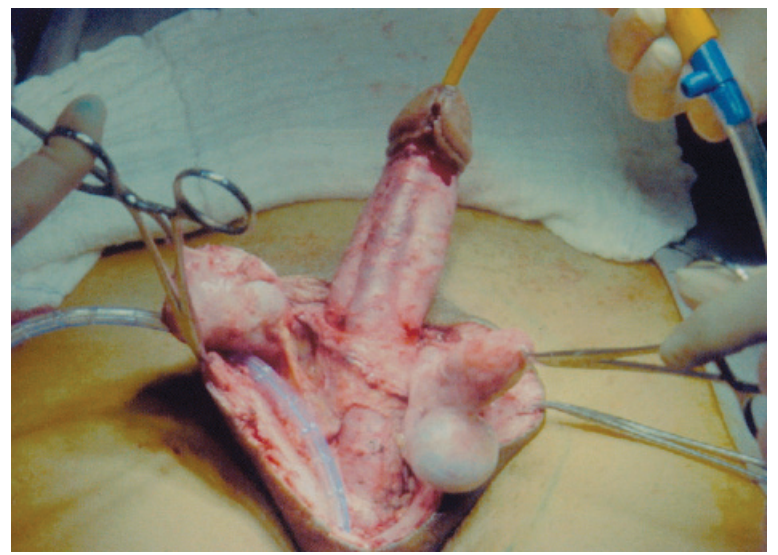

Figure 3 - (Patient 7 of Table 1) - Transoperative period showing the penile shaft, testes and spermatic cords after resection of affected penile and scrotal skin

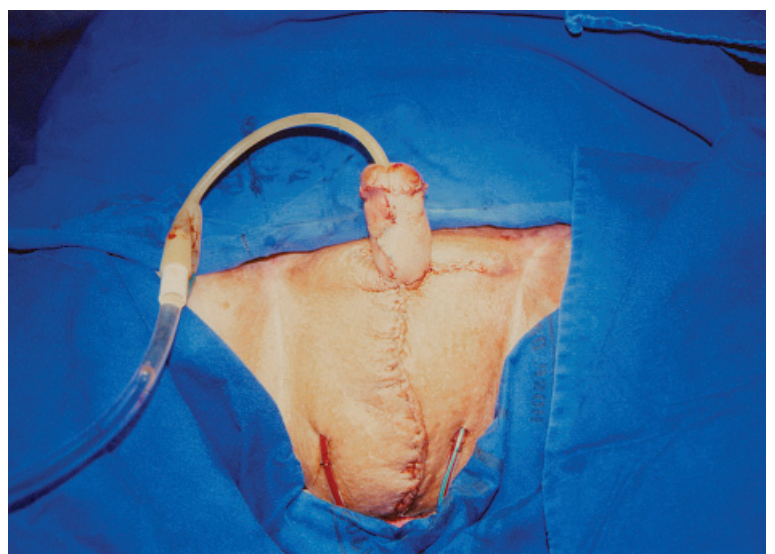

Figure 4 - (Patient 3 of Table 1) - Immediate postoperative period showing zigzag suture over the graft on the ventral surface of the penis

An occlusive dressing consisting of a mild compression bandage to ensure adequate contact of the graft with the recipient bed was left in place for 3 days. The patient remained with an indwelling urinary catheter for the same period (Figure 5). The scrotum was cleansed daily and kept with a scrotal suspensor.

\section{RESULTS}

Although the postoperative evaluation was subjective both on the part of the surgical team and of patients, a clear improvement of the aspect of the external genitalia (Figures 6A and 6B) and subsequent improvement of ambulation, hygiene, and ability to void in the standing position were observed. The improvement of sexual performance could not be directly assessed, although some

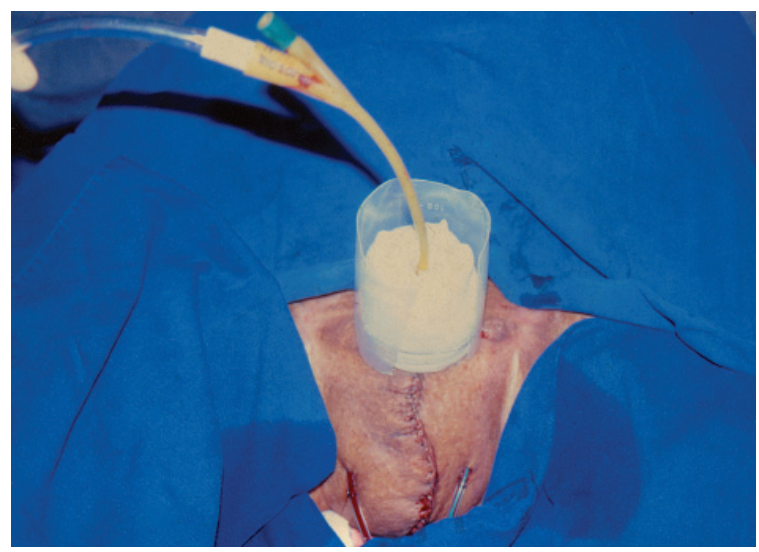

Figure 5 - (Patient 3 of Table 1) - Immediate postoperative period showing dressing around the penile shaft

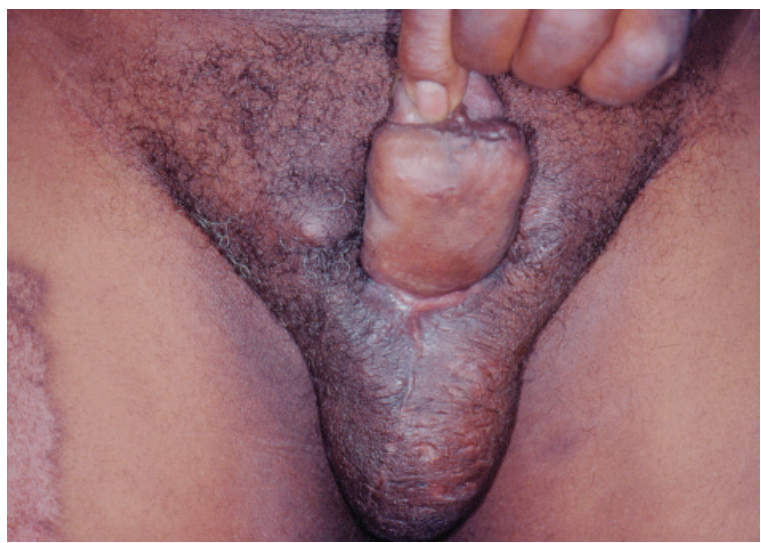

Figure 6A - (Patient 1 of Table 1$)$ - Late postoperative period - 6 months showing scars on the ventral surface of the penis and scrotum

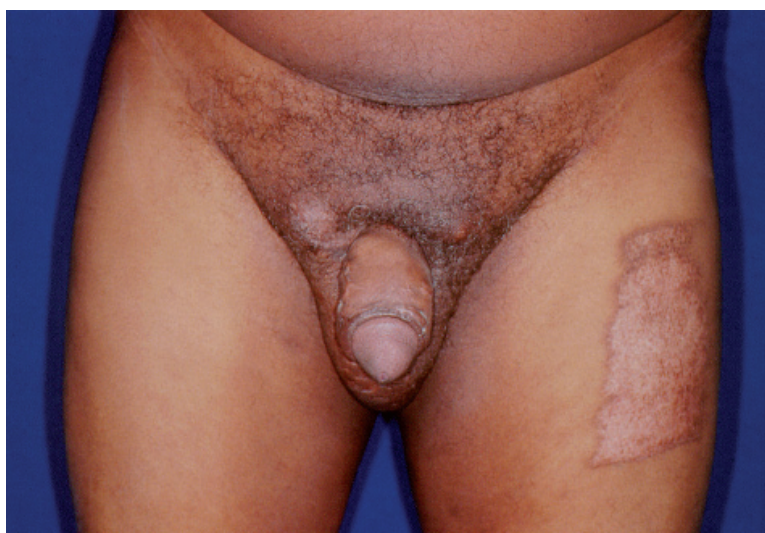

Figure 6B - (Patient 1 of Table 1 ) - Late postoperative period - 6 months showing satisfactory scrotal and penile coverage with no retractions

patients stated that sexual intercourse became more effective as regards penetration and satisfaction for patient and partner.

Data regarding patients' ages, duration of the disease, etiology of the penoscrotal lymphedema, and follow-up period are shown in Table 1 . 
The patients were followed postoperatively for a minimum 6-month and maximum 6-year period, during which only 1 patient who had undergone surgery with inguinal lymphadenectomy and radiation therapy because of penile cancer had recurrent scrotum lymphedema. He underwent a reoperation 2 years after the previous procedure and had a new recurrence, making a reintervention necessary. The patient had a favorable outcome in the long-term follow-up.

Although this surgical site is subject to contamination because of neighboring structures, no infections, dehiscence, or necrosis was observed, probably thanks to technical care and proper local hygiene.

\section{DISCUSSION}

Penoscrotal lymphedema is a condition leading to the progressive enlargement of the scrotum and penis causing significant discomfort for patients. In addition to the grotesque aspect, the progression of the condition impairs ambulation, makes sexual intercourse impossible, and impairs both voiding in the standing position and proper hygiene of the perineal region, with subsequent malodor and recurrent episodes of skin infections, resulting in cellulitis and lymphangitis, thus aggravating the anatomopathological presentation and causing severe damage to the patient's quality of life and self-esteem. . $^{1,4,5,7}$

The lymphatic obstruction of the superficial chain of the inguinoscrotal region, responsible for the lymphatic drainage of the penile and scrotal skin, results in elephantiasis of the external genitalia. The deep chain is responsible for lymphatic drainage of the testes and penile body and flows into deep inguinal and abdominal lymph nodes, and is usually preserved.

Clinical treatment with different approaches has proven inefficient and is no longer used. . $3,3,10,12,13,15,16^{-10}$

Surgical treatment based on lymphangioplasty aimed at restoring lymphatic drainage with vascular anastomoses is limited to cases with minor stasis, well isolated lymphatic channels, and no fibrosis. ${ }^{3}$ Failures in this surgical procedure and frequent recurrences have discouraged the use of this technique.

Lymphangiectomy consists of complete resection of affected penile and scrotal tissues, and is perfectly feasible without affecting penile and testis structures, provided there is expertise in the anatomy of the regional lymphatic chains. $^{8,18}$

The inversion of the tunica vaginalis aims at treating hydrocele, which is always associated with scrotal lymphedema in varying degrees. Frequently, the distension of adjacent tissues enables the reconstruction of the scrotum, accommodating the spermatic cords and testes.

The excision of all the affected penile skin is a fundamental principle for the adequate treatment of this condition and for proper resumption of the sexual function. ${ }^{10}$ The major challenge is to reconstruct the penile skin, and countless techniques for this procedure are part of the surgical armamentarium. ${ }^{8-10,14-16}$

The application of a split-thickness skin graft involving the penile shaft promotes adequate skin coverage, with a penile girth compatible with sexual intercourse and little alteration in sensitiveness, as some patients report. The zigzag suture of the graft on the ventral surface of the penis, a tactic that is here proposed, is, in our opinion, a key point in reconstruction, insofar as it aims at avoiding scar contracture and subsequent ventral curvature of the penis.

Comparing this management technique with those described in the literature, ${ }^{1-4,8,17}$ we can state that the principles of penile reconstruction were observed. As a matter of fact, the coverage of the penile shaft with splitthickness skin graft is much better than the use of flaps, even local flaps, which notably affect tactile sensitivity and erection ${ }^{2,8}$ and could require supplementary surgical procedures to correct occasional sequelae.

Scrotum reconstruction after complete excision of the affected skin by using adjacent skin tissue has proved to be adequate and with late results providing a scrotum appearance close to normal. The suture line simulates the median raphe, providing a natural appearance to the scrotum. Tissue elasticity, the volume of the testes themselves, and the gravitational effect prevent scar contracture, so that the Z-plasty suture becomes unnecessary. ${ }^{8,11}$

The recurrence experienced by 1 patient was due to resection of inguinal lymph nodes and subsequent radiation therapy for the treatment of penile cancer with permanent impairment of the superficial lymphatic drainage, and was the only recurrence seen in the present case series.

\section{CONCLUSIONS}

Although a validated questionnaire to assess quality of life was not applied, we could observe in the follow-up period ranging from 6 months to 6 years that, with the exception of 1 patient who had recurrence due to the underlying disease, the treatment of penoscrotal lymphedema with a modified Charles procedure with Z-plasty of the penile skin graft allowed a more effective hygiene and consequent reduction of infections, easier ambulation, voiding in the standing position, better cosmetic results to the ex- 
ternal genitalia, and made sexual intercourse more satisfactory, although the latter was only assessed subjectively by some of the patients. All these factors contributed to the patients' social and professional reinsertion, which in itself corroborates the improvement of the quality of life.

\section{ACKNOWLEDGMENT}

The auctors wish to express their knowledgment to Dra. Eliana Taira who helped in the elaboration of the text of this article.
Modolin M, Mitre AI, da Silva JCF, Cintra W, Quagliano AP, Arap S, Ferreira MC. Tratamento cirúrgico do linfedema peno-escrotal. Clinics. 2006;61(4):289-94.

INTRODUÇÃO: O linfedema peno-escrotal, independentemente da etiologia, é determinado pela redução do fluxo linfático com conseqüente aumento do volume do escroto e pênis. A evolução clínica da doença é caracterizada com extremo desconforto ao paciente, limitando a higiene local, a deambulação, o intercurso sexual e a micção em posição ortostática.
OBJETIVO: Apresentar a experiência e resultados no tratamento da patologia com remoção dos tecidos comprometidos e correção peno-escrotal.

MÉTODO: Foram tratados 17 pacientes com linfedema do escroto e pênis com a técnica de Charles modificada, que consiste na excisão da pele comprometida seguida de escrotoplastia e sutura mediana simulando a rafe escrotal. O pênis é recoberto com enxerto de pele parcial suturado em linha quebrada na face ventral.

RESULTADOS: No seguimento dos pacientes, que variou entre 6 meses e 6 anos, constatou-se regressão dos sintomas 
e melhora das condições clínicas prévias. Um paciente submetido à linfadenectomia com radioterapia por câncer de pênis teve recidiva do linfedema escrotal.

CONCLUSÃO: A técnica de Charles modificada no tratamento do linfedema peno-escrotal é facilmente reprodutível e possibilita com seus resultados melhor higiene local, melhor movimentação, micção em posição ortostática, retomada do intercurso sexual e, finalmente, melhor aparência à região comprometida com franca melhora da qualidade de vida.

UNITERMOS: Elefantíase, Linfedema, Peno-escrotal, Linfangectomia, Tratamento cirúrgico.

\section{REFERENCES}

1. Bulkley GJ. Scrotal and lymphedema. J Urol. 1962:87:422-9.

2. Dandapat MC, Mohapatro SK, Patro SK. Elephantiasis of the penis and scrotum - a review of 350 cases. Am J Surg. 1985:149:686-90.

3. Sauer PF, Bueschen AJ, Vasconnez LO. Lymphedema of the penis and scrotum. Clin Plast Surg. 1998:15:69-78.

4. Farina R, Farina G. Elefantíase peno-escrotal (osqueofaloplastia). Rev Bra Cir. 1995:85:20512.

5. Gonella HA. Linfedema peniano. Rev Bra Cir. 1967:72:23-6.

6. Yormuk E, Sevin K, Emiroglu M, Turker M. A new surgical approach in genital lymphedema. Plast Reconstr Surg. 1990:86:1194-7.

7. Prpic I. Severe elephantiasis of penis and scrotum. Br J Plast Surg. 1966:19:173-8.

8. Apesos J, Anigian G. Reconstruction of penile and scrotal lymphedema. Ann Plast Surg. 1991:27:570-3.

9. Feins NR. A new surgical technique for lymphedema of penis and scrotum J Ped Surg. 1980:15:787-9.

10. Goldsmith HS, Los Santos R, Beattie EJ. Relief of chronic lymphedema by omental transposition. Ann Surg. 1967:166:573-85.
11. Charles RH. The surgical technique and operative treatment of elephantiasis of the generative organs based on a series of 140 consecutive successful cases. Ind Med Gaz. 1901:36:84.

12. Dumanian GA, Futrell JW. The Charles procedure: misquoted and misunderstood since 1950. Plast Reconstr Surg. 1996:98:1258-63.

13. Gillies H, Frazier FR. Treatment of lymphedema by plastic operation. Br Med J. 1935:96:96-9.

14. Kedroo LG. Reduction perineoplasty scrotal elephantiasis: a method of surgical reconstruction of penis and scrotum. J Urol. 1976:116:67980.

15. Modolin M, Mitre A, Quagliano AP, et al. Tratamento cirúrgico do linfedema peno-escrotal: relato de caso. J Bras Urol. 1998:24:106-8.

16. Sun GS, Zhong AG, He W, Du P, Song WM, Ma JG. Reconstruction of the external genitals and repair of skin defects of the perineal region using three types of lateral groin flap. Ann Plast Surg. 1990:24:328-34.

17. Favager N, Rist M, Krupp S. Reconstruction cutanée des organes genitaux externes: une ancienne méthode toujours d'actualité. Helv Chir Acta, 1991:58:301-3. 